\title{
New Quality of Education in the Context of Its Digitalization
}

\begin{abstract}
Belyaeva L.A.
Ural State Pedagogical University, Yekaterinburg, Russia

Email: labelyaeva278@mail.ru

ABSTRACT

Contemporary society has a large number of definitions. It is called the post-industrial civilization, information society, society of knowledge, and finally society of numbers. All these definitions reflect diversity of novelty that is a characteristic feature of modernity, and indicate the beginning of a new "axial time" in the history of mankind, when a technological breakthrough has made it necessary to amend the essence of many social and cultural phenomena, and especially education, which serves as a bridge to the future. Today, it is important to use foresight technologies to determine what quality characteristics should be gained in education in a new historical context that has created new challenges and requires new answers. The article proposes a system-synergetic five-component model of a new quality of education. There have been the challenges of digitalization and globalization of education and some of their socio-cultural consequences analyzed in the article.
\end{abstract}

Keywords: new quality of education, system-synergetic approach, digitalization of education, globalization of education, educational foresight

\section{INTRODUCTION}

A characteristic feature of life of contemporary society has become a permanent process of modernization of education, as a response to the crisis state of educational system. It manifested itself in a decline in authority of knowledge, spirituality, devaluation of prestige of intellectual work, dissatisfaction with work of the school, which is especially brightly demonstrated in its final result. It often leaves young people with rather outdated knowledge, not ready for independent life choices and work, unable to take responsibility, and mostly important, "average", with no identified individual creativity, confused values and relativistic morality.

Education crisis affected not only our country, but also developed countries of the West, where it was discovered much earlier. Since the 60-70s, there were discussions about the world crisis of education, which were participated by famous teachers, philosophers, futurists, such as F. Coombs, T. Hewsen, A. Toffler, I. Illich, I. Zilberman, and others.

The first wave of education reforms in the West took place in the 60 s and early $70 \mathrm{~s}$.

As the result, duration of training has been extended, the network of extracurricular and post-secondary education has expanded, and the system of life-long education has begun to develop. However, all this did not bring desired results.

In the end, during discussions it was concluded that the essence of educational crisis is discrepancy between the existing educational system, the content and methods of training and upbringing of a new high-tech information civilization that is replacing the industrial society.

\section{METHODOLOGY OF THE RESEARCH}

One of the drawbacks of the existing systems of education is the lack of clear methodological basis of transformation of modernization, which is primarily connected with crudity of modern philosophy of education, adequate to realities and prospects of social development. There should be a new approach based on modern methodology, a serious philosophical justification of place and role of education in society, based on foresight of the future.

One of the social technologies that is gaining popularity in social and humanitarian knowledge today is foresight technology, which was created more than 30 years ago in the West on the basis of a synergetic methodology, the subject of this research is complex systems that have an ability to self-development. Synergetics (G. Haken, I. Prigozhin, N. N. Moiseev, E. N. Knyazeva, S. P. Kurdyumov) showed that development of such systems is nonlinear, and therefore self-developing systems cannot be imposed on the path of development dictated by the past. Effective management of self-developing systems should be carried out not from the past, but from the future state of the system. Hence, such technologies as development of future scenarios (G. Kahn) and foresight technologies aimed at foreseeing and developing steps to bring the desired future closer. This fundamentally changes the nature of goal-setting, the choice of means and influences 
on the expected (desired) result. Moreover, the implementation of these technologies also changes the nature of socio-cultural dynamics, in which the emphasis of managing complex systems is transferred from the past to the future, trying to foresee and anticipate the desired future.

This methodology is very significant for modernization of education, since education is a bridge to the future, and therefore today we need to teach what will be required in the future. Today, it is important to anticipate a new quality of education - education for the future.

\section{DISCUSSION AND THE RESULTS}

The question of what the essence of education today is that the American researchers C. Feidl, M. Bialik, and B. Trilling begin their widely acclaimed book "4-D Education". Based on their long-term research, they conclude that four-dimensional education includes four components: "knowledge, skills, character, and metalearning" related to the development of creativity and critical thinking [11, p.20]. Even earlier, E. Toffler in his work "Shock of the future" expressed the idea that education for the future should pursue three goals: teach to learn, teach to communicate and teach to choose. [5, pp. 449-455].

As we know it, the concept of "new quality of education" includes five components: a new strategy of education; a new content of education; a new technological basis of education; a new generation teacher with new pedagogical thinking and new philosophy of education as a methodological and ideological basis for up-to-date understanding of education.

Based on the foresight methodology, it is necessary to understand the challenges of our time correctly and formulate adequate responses to these challenges. The first thing that should be done is to develop a new strategy for educational system based on prospects of social development, digitalization of the economy and the demand to solve global problems facing humanity, on the one hand, and the need to identify individual creativity of the individual, on the other hand. New quality of education necessarily implies development of new approaches to updating the content of education, which would be consistent with requirements of a new strategy and a new social context of a society characterized by informatization and digitalization, which naturally determines necessity of creating and using new educational technologies based on personal computers, video equipment, etc.

The most important challenge of the modern era is the Internet as a source of all kinds of information. In postmodern society, information becomes one of the most popular items of consumption, bringing a consumer satisfaction with its accessibility and illusion of a possibility of omniscience.

However, the problem is that information and knowledge are not the same thing. Information is "data of something", but knowledge is mentally processed and assimilated information. Education at all times has been aimed at providing students with knowledge brought into a system on the basis of which understanding grows as the ability to think independently. As it is shown in numerous researchers today, in the process of fleeting acquaintance with a large amount of information, a person forms clip thinking, which is characterized by fragmentation, lack of system, integrity, inability to rise from the empirical level to the level of theoretical generalizations, and the language game, drawing a person into virtual reality, absorbs the time of true human existence.

Meanwhile, today, and even more in the future, intellectual abilities of a person turn into the most important capital of society, thanks to which it becomes possible to generate new knowledge and new meanings. Consequently, the formation of competencies that allow to activate cognitive potential of an individual is the most important task of education, which determines its quality, expressed in metacompetencies or culture of thinking. The culture of thinking involves not just getting information, but its processing, analysis, identifying the main idea, understanding the meaning, ability to generalize and formulate hypotheses. In the theory and practice of modern management there is a well-founded position that success of an organization today is determined by intellectual capital, which becomes "the main value of any organization and a significant factor in the competitive struggle" [4, p. 51].

The quality of education is, of course, closely connected with its content. How to make sure that education is free from knowledge that is not in demand in life, and at the same time not to surrender to the temptation of positivism (O. Comte, G. Spencer, etc.), which supposes that only that knowledge is significant that has direct practical use. Inattention to fundamental knowledge and lack of an interdisciplinary approach, problem teaching lead to formation of constricted professionalism and inability to implement professional mobility in the rapidly changing world, and clip thinking aggravate this problem.

It should be noted that modern tendencies in updating the content of education are set by philosophy of education, a strategy of its development, existing problems and offer, in our opinion:

- optimal combination of fundamental (academic) and empirical (applied, practice-oriented) components. It should be taken into account that it is a fundamental component of the content of education that contributes to the growth of graduate's competitiveness, increases a degree of his/her professional and social adaptability and mobility;

- strengthening of socio-anthropological training aimed at personal identification, development of social and personal competencies;

axiological education, saturation of its axiological content, orienting individuals in the system of values that helps to develop their own value-semantic core of the worldview and motivation of the choice;

- developing a system of additional education and defining its contents to provide educational services in accordance with individual educational needs and requirements of the labour market. 
But the most radical changes in modern education and a significant impact on its quality today and in the future is the technological revolution, which forms new methods and tools for educational activities. They include information technologies for searching and processing information, distance learning, the use of educational platforms, augmented and virtual reality, interactive methods of engagement in the educational process using a computer and the Internet.

Great hopes are anchored on online education, transition to which in foreign literature is defined as "undermining" the modern education system. Numerous works of modern researchers are devoted to discussion of problems of transition to mass open online education. The authors of these researches analyze distinctive features of online education in comparison with traditional education $[9,10]$, besides they raise a question whether online education is an adaptive model of education or it presents a business model that promises greater commercial benefits [7].

Our country is also concerned about the use of information technologies in education in the era of digitalization. In accordance with the Federal project "Digital educational environment" of the National project "Education", the main task of the project will be solved by 2024. That is preparing the necessary quality content for online education of schoolchildren by creating and implementing an information and service platform for the digital educational environment. This will lead to the fact that a significant part of school time will be spent online in searching necessary information and solving educational tasks offered by the platform modules of educational tasks [8].

Gradual replacement of the classroom system as a technology of education in industrial society, which was an approximate analog of conveyor production, will certainly require new temporary, spatial and meaningful organizational forms of education, both at school and at University, and will introduce significant changes in all components of educational system. First of all, it will significantly change the place and role of participants of educational activity. In online education, the degree of freedom of students increases, but at the same time a level of responsibility for results of their self-educational activity increases, in which a weakening external control should be enhanced with a significant amount of selfcontrol.

And here there may be a problem of failure of students who did not cope with the task of self-control. For example, a number of authors (O. A. Blinova, I. G. Chugayev), who analyze present issues of informationeducation environment of a primary school child in the sample of the web portal "Teach.ru" claim that a student is left to himself, the program shows a mistake, but does not explain what it is and why it can happen. There is no direct relationship of a teacher and a student [2, p. 18-20].

New models of education based on information technologies significantly change the character of another component that is most significant in the traditional education system. That is pedagogical activity, which we consider as a way of education being, defining education as interpersonal communication in the space-time continuum of socio-cultural fields, aimed at understanding and common ground.

What is happening to teaching activities in the context of the use of digital technologies in educational process? First of all, it should be noted that online education is changing the nature of communication between a teacher and a student. Personal communication of teachers and students in a significant extent will be mediated, which will affect development of personal characteristics of a student. Thus, there is another important problem that affects the quality of education, whether technical devices can form personal qualities, a system of value orientations of students. Today, a teacher does not only conduct lessons, explain material, conduct surveys and assess students' knowledge, he/she solves new tasks: creating a school informationeducational environment, a database of electronic lessons, forming and developing the ability to use an interactive whiteboard, tablets, electronic applications to educationalmethodical materials and databases.

There are also new concerns for a family, for which a function of monitoring education of students in online technologies is willingly or unwittingly shifted responsibilities from school and teachers on parents. This is especially true for the "inverted classroom" educational model, when children will spend a significant part of their school time (up to $60 \%$ ) at home at the computer, looking for interesting content, and it is not a fact that these will be educational materials, and not those that take away from educational process. The problem of students ' health care is also becoming more acute, since keeping to a rational regime of study and recreation is also given to students' complete control .

But the main prerequisite and basis for a qualitatively new state of educational system of society should be a new philosophy of education, which could anticipate image of a person of digital age and equip education system with new worldview and value orientations that are consonant with this understanding. New, modern philosophy of education, which is replacing philosophy of education of the Age of Enlightenment (XYIII century), will also serve as necessary theoretical, methodological and ideological foundation for development of new pedagogical thinking, without which a new quality of education is unachievable. It is development of new pedagogical thinking based on new, modern philosophy of education that is a necessary condition for moving to a new quality of education and, as a result, to a new quality of life. Education fulfills a number of important social functions, underestimation of which leads to decrease in the quality of life and, ultimately, to the spiritual and physical degradation of a man and society. The most important social functions of education are: a function of social inheritance, i.e. preservation and transmission of culture from generation to generation; a function of socio-cultural reproduction of a person and society. History itself doesn't do anything. Everything is done by people on whose moral and spiritual qualities the actions they perform depend.

New pedagogical thinking can be defined as thinking that is based on new philosophy of education, including a new 
worldview and a new idea of man, his place in the world and purposes of his existence, philosophical ideas about historically emerging models of education, socio-cultural reproduction of a man, development of his corporeality and spirituality. The most important goal of the new philosophy of education and new pedagogical thinking is to developing such a model of education that would:

- correspond to new historical realities associated with the need to resolve overdue contradictions in development of modern society, including the Russian one;

- correlate with the need to transition to a new stage of industrial civilization, that is information society;

- satisfy the needs of every individual in a holistic development, formation of spiritual world of an individual, inseparable from contradictions of scientism and antiscientism, technocratism and humanism

As far as the key role in achieving a new quality of education and a new quality of life of all members of society is played by a teacher, because primary importance is given to modernization of pedagogical education, which task is to prepare teachers of a new format. To do this, it is necessary to revise the concept of teacher's professionalism, taking into account a new historical task

\section{CONCLUSION}

Having considered the problem of new quality of education in the context of digitalization of education, we came to its system-synergetic understanding as interrelation and interaction of five components, systemforming of which is its philosophical paradigm. The paradigm of modern education should be education for personal development based on self-motivation and selfdesign based on values and meanings that have both social and personal significance."

Education as means of social-cultural reproduction is to reproduce not only the person knowing (cognitive component), capable (pragmatic component), but also a one who understanding, who is able to self-projecting and self-realization, independent in choosing values and meanings (axiological component) [1, p. 5].

According to our strong belief the main focus should be directed not only on success of an individual fate and the fate of other people/ That is especially important in the context of informatization and digitalization of modern society, and development of artificial intelligence

\section{REFERENCES}

[1] Belyaeva, L.A. (2008), “Education in the context of globalization: trends of development", Education and science ["Obrazovanie v kontekste globalizacii: tendencii razvitiya”, Obrazovanie i nauka], No 5 (17), pp. 3-9.

[2] Blinova, O. A., Chugaeva, I. G. (2018), " Formation of educational environment of primary school children of digitalization of education. Today, we need a teacher with an innovative style of thinking, capable of professional mobility and adaptability, and independent creative growth. In this regard, the most important task of science and practice is to develop programs and develop a flexible system of professional development and retraining of teachers

And since the key role in achieving new quality of education and new quality of life for all members of society is played by a teacher, the primary importance is given to the modernization of pedagogical education, whose task is to train teachers of a new format. For this purpose, it is necessary to overview the concept of teacher's professionalism, taking into account a new historical task of digitalization of education. Today, we need a teacher with an innovative style of thinking, capable of professional mobility and adaptability, and independent creative growth. In this regard, the most important task of science and practice is to develop programs and develop a flexible system of professional development and retraining of pedagogical staff.

Modern philosophy of education points up on the need to educate people in the spirit of responsibility and freedom, development of intelligence and spirituality, awareness of the role that a man plays not only in the earthly, but also in Modern philosophy of education focuses on the need to educate people in the spirit of responsibility and freedom, the development of intelligence and spirituality, awareness of the role that man plays not only on the Earth, but also in global processes. Educational system should teach a person to live their life in a meaningful way, to understand contradictions of social and his/her own development and ways to resolve problems.

Thus, it should be said that there is a new "axial time" in the history of mankind today, when technological breakthrough has made it necessary to review the essence of what education is, what quality characteristics it should have in a new historical context that has created new challenges and requires new answers.

via information- communication technologies": Humanitarian and pedagogical research ["Formirovanie obrazovatel'noj sredy mladshego shkol'nika posredstvom informacionno-kommunikacionnyh tekhnologij”, Gumanitarno-pedagogicheskie issledovaniya], Vol. 2, No 1, pp. 12-23. 
[3] Borisov, S. V., Azarova, Yu. O., Anahov, S. V., Arpent'eva, M. R. and others., (2018), Education of the future and education for the future, Philosophy and science: methodology of scientific search [Obrazovanie budushchego i obrazovanie dlya budushchego, Filosofiya i nauka: metodologiya nauchnogo poiska], Publishing house of the Yekaterinburg Academy of contemporary art, Yekaterinburg, 292 p.

[4] Senge, P. (2003), the Fifth discipline. The art and practice of self-learning organizations [Pyataya disciplina. Art and practice of self-learning organizations], Olimp-Biznes, Moscow, 408 p.

[5] Toffler, E. (2002), Shock of future [Shok budushchego], Izd-vo AST, Moscow, 557 p.

[6] Tul'chinskij, G.L. (2017), “The digital transformation of education: challenges in higher education", philosophy of science ["Cifrovaya transformaciya obrazovaniya: vyzovy vysshej shkoly", Filosofskie nauki], No 6, pp. 121-129.

[7] Daniel, J., Vazquez C.E., Gisbert, M. (2015), “The Future of MOOCs: Adaptive Learning or Business Model? RUSC", Universities and Knowledge Society Journal, No 12 (1). pp. 64-73.

[8] European Commission (2013), Survey of Schools, available at: https://ec.europa.eu/info/index_en (In English)

[9] Reeves, T., Hedberg, J. (2014), “MOOCS: Let's Get REAL", Educational Technology, Vol. 54, No 1, pp. 3-8.

[10] Siemens, G. (2013), "Massive Open Online Courses: Innovation in Education?", Open Educational Resources: Innovation, Research and Practice, Athabasca University, Vancouver, pp. 5-16.

[11] Fadel, C., Bialik, M., Trilling, B. (2015), ForeDimensional Education: The Competencies Learners Need to Succeed, Center for Curriculum Redesign, Boston, $192 \mathrm{p}$. 